City University of New York (CUNY)

CUNY Academic Works

Publications and Research

Baruch College

Fall 2001

\title{
The Lunatic's Fancy and the Work of Art
}

Shelly J. Eversley

CUNY Bernard M Baruch College

\section{How does access to this work benefit you? Let us know!}

Follow this and additional works at: http://academicworks.cuny.edu/bb_pubs

Part of the African American Studies Commons, and the American Literature Commons

\section{Recommended Citation}

Eversley, Shelly J., "The Lunatic's Fancy and the Work of Art" (2001). CUNY Academic Works.

http://academicworks.cuny.edu/bb_pubs/112

This Article is brought to you for free and open access by the Baruch College at CUNY Academic Works. It has been accepted for inclusion in Publications and Research by an authorized administrator of CUNY Academic Works. For more information, please contact

AcademicWorks@cuny.edu. 


\section{The Lunatic's Fancy and the Work of Art}

Shelly Eversley

It was as though I had entered a haunted wood wherein every detail of scene, each thought and incipient action, sprang together and became endowed with a surreal and sinister significance. Almost everything about me seemed bent upon contributing to my growing sense of the irrational disorder of life ...

Ralph Ellison, Invisible Man

Yes, sane men did misread reality. Just as he had once had fantasies, so now he was looking at men who were passionately arguing their own fantasies, trying to decide which fantasy was to be taken for reality.

Richard Wright, The Outsider

When the Lafargue Psychiatric Clinic opened in Harlem in 1946, one newspaper responded with a headline, "They're Crazy Anyway." The clinic was the first of its kind; it offered counseling to poor people, mostly black, but regardless of race or ability to pay. According to Richard Wright, whose essay "Phychiatry [sic] Comes to Harlem" (1946) was specifically meant to increase the clinic's publicity and financial support, it "is the extension of the very concept of psychiatry into a new realm, the application of psychiatry to the masses, the turning of Freud upside down." In its practice the clinic rejected abstract notions of psychoanalytic neurosis to address what became understood as social and artificially induced crises: "Negroes temporarily swamped by the Jim Crow conditions of Harlem ... the powerful personality conflicts engendered in Negroes by the constant sabotage of their democratic aspirations ... which easily tips the emotional scales toward neurosis" (49-50). It appeared underground (literally, in 
By midcentury, increasing national and international demands for an exemplary democracy required a reconfiguration of US racial ideology, and rather than $a$ question of color, of visible and public difference, this new "Negro Problem" became one of psychology and feeling, forcing the terms of race and the social and ethical implications of racial distinction out of sight. the basement of a church) and without institutional recognition or financial support. ${ }^{1}$ According to its well-known founder and director, psychiatrist Dr. Frederic Wertham, the clinic sought to treat patients whose "mental difficulties" arose out of the "freefloating hostility" that emerged from poverty, from congested living conditions, and, most importantly, from segregation (Bendiner 23). ${ }^{2}$ Wertham, other volunteer psychiatrists, and mental hygiene professionals who donated their time, specifically attempted to address what they understood as the interior and intangible effects of racial discrimination-a problem Ralph Ellison describes as "the sickness of the social order." In an article written to support the clinic, Ellison contends that black people had become "confused" by a paradox: the reality of racist social inequality in the US and the nation's postwar reputation as champion of democracy had exposed the "psychological character" of "the Negro's perpetual alienation in the land of his birth" ("Harlem" 295, 302). The paradox had threatened the recognition of black American humanity and had implicated the integrity of democracy in the US. Thus, both Ellison and Wright applauded the emergence of the Lafargue Clinic-they helped Wertham secure the space, the clients, and the funds for its opening. ${ }^{3}$ And, rather than offering "proof" that, in fact, black people were "crazy anyway", the clinic presented a psychological discourse to enunciate the implications and the new contours of what had been called the "Negro Problem," the "problem at the heart of every American" (4), in the words of Gunnar Myrdal's An American Dilemma: The Negro Problem and Modern Democracy (1944), as the nation began to imagine integration.

As a significant but largely forgotten underground institution, the Lafargue Clinic indeed represents the material embodiment of an emerging era-one that understood the crucial difference between "black" and "white" as moving beneath the surface and turning inward. ${ }^{4}$ By midcentury, increasing national and international demands for an exemplary democracy required a reconfiguration of US racial ideology, and rather than a question of color, of visible and public difference, this new "Negro Problem" became one of psychology and feeling, forcing the terms of race and the social and ethical implications of racial distinction out of sight. Concerning psychoanalysis, Wertham believed "a psychiatrist had to understand a patient's economic and community life," and he advanced an idea that "psychoanalysis and psychotherapy are not the property of the rich." $\mathrm{He}$ called his approach to psychoanalysis "social psychiatry" and argued "the real truth about an individual is always social" (Martin 798). Because "man is a social creature," Wertham wrote 
in the New Republic, "the connection between individual development and social causation must be the test of the value of any psychology" (129). As a result, the Lafargue Clinic had the potential to demonstrate through psychological discourses the social implications of the contradictory persistence of racism at midcentury. It addressed its patients' symptomology not as "lunacy" but as reasonable psychic responses to the lunatic obsessions of US white supremacist culture, and its practice informed the narrative focus and strategy Wright and Ellison adopted in their postwar fictions. In a 1945 essay for the New Republic, written while he worked to establish the clinic, Ellison described the US as "a nation of ethical schizophrenics": "The unwillingness to resolve the conflict in keeping with his democratic ideals has compelled the white American, figuratively, to force the Negro down into the deeper level of his consciousness, into the inner world, where reason and madness mingle with hope and memory and endlessly give birth to nightmare and dream; down into the province of the psychiatrist and the artist, from whence spring the lunatic's fancy and the work of art" ("Beating" 99-100). Implicit in his statement is a striking equation that the unresolved tension between segregation and democracy inadvertently produces a new alliance-between psychiatry and art-which I want to argue defines the most important black literary production of the late 1940s into the 1950s. The Lafargue Clinic continued to operate until 1959; its years of operation coincide with a moment in American literature in which the artist selfconsciously engages psychiatry. ${ }^{5}$ At this moment, Ellison's and Wright's work enact a historical turn toward psychology particularly as it enunciates the emerging contours of a "schizophrenic" American democracy and American literature.

The literary engagement with social relations, their moral implications and their corresponding psychological manifestations, represents a conscious risk, one that emphasizes the willful desire for full humanity at a transitional moment when deracialized public space and "universal" literature seems within reach. ${ }^{6}$ Like most African-American authors before them, Ellison and Wright participate in a long-standing, traditional commitment to the equation between black literature and black humanity, but here their deliberate portrayals of individual mental processes for the first time imagine a freedom from what Claudia Tate has recently called "racial protocol." She argues that the conventions that define black writing privilege visible instances of racial protest and a public, collective identity while they suppress representations of private, individual desire. Her psychoanalytic reading of black novels describes pervasive "unconscious desires that not 
only refuse to remain subordinate to the intentional story but also unsettle the sanctioned social plot of identity" (12). But, unlike Tate's notion of an unresolved tension between public racial identity and unconscious private desire, Ellison's and Wright's commitment to the interaction between psychology and literature seeks to resolve the conflict between public and private, the race and the individual, the particular and the universal. Also, as a conscious move, they claim an agency the unconscious denies-"the turning of Freud upside down." The narrative choices in Ellison's "King of the Bingo Game" (1944) and Invisible Man (1952) and in Wright's Rite of Passage (1944) reflect the authors' emerging interests in psychology, conversations with Wertham, and specifically, their plans to establish the clinic. Like Wright's The Outsider (1953), these postwar fictions risk exposing a "neurosis" not in the black writer, but in the reader. The reader becomes not a voyeur safely distant and untouched from the scene, but a participant whose behavior reveals a more dangerous "sickness." This notion of conscious risk deploys a critique of neurosis that is understood abstractly and ahistorically. It challenges the Freudian psychoanalytic emphasis on the primary nurturing environment while it also turns a critical eye toward an emerging social psychology and social psychiatry and their interest in external conditions-racialist culture and democracy. Thus for Ellison and Wright, American culture and American democracy stand to lose if black people are "crazy anyway." Within the risk on which their engagement with art and psychiatry stands, African Americans are not crazy, they just appear that way. Once past the superficialities of color and once inside the "inner world" of psychology, the problematic culture, not a people, can be exposed and then "cured."

Ellison employs the language of repression to illustrate the "schizophrenia" of the political order. Whites are "unwilling to resolve the conflict" of segregation and democracy, he argues, and in their repression, they "force the Negro down into deeper levels of his consciousness." Consequently, "the Negro problem" is not Negro at all. Rather, a "heart-lashing sea of irrationality," perpetuated by whites, causes the problem that results in "a nightmarishly 'absurd' situation" for whites and for segregated black people ("Beating" 96). In "Harlem Is Nowhere" (1948) Ellison celebrates the Lafargue Clinic because it "represents an underground extension of democracy" by seeking to dissolve invidious racial difference and segregation (295). In its nondiscriminatory approach to mental health, the clinic offers a constructive solution to the "unreality," metaphorized as ethical schizophrenia, that is the inequality forced daily upon its patients. Concern- 
ing segregation, he writes, "when Negroes are barred from participating in the main institutional life of society they lose far more than economic privileges.... They lose one of the bulwarks which men place between themselves and the constant threat of chaos." For Ellison, the denial of this "bulwark" of institutional life renders the Negro individual "nowhere," figuratively out of sight and beneath social significance. Ultimately, this denial, or "invisibility," "leaves the most balanced Negro open to anxiety," feeling that she or he has "no stable, recognized place in society" (298-300). Notably, that placelessness anticipates pervasive literary characterizations of social psychology by African-American authors that begin to emerge in the 1940s and climax in the 1950s.

In their support for segregation and in their repression of the fundamental contradiction within their democratic principles, white Americans, according to Ellison, impose interpretations of Negro experience that not only are false, but also amount to a denial of black humanity. The result is "an argument in progress between black men and white men as to the true nature of American reality." Although the conflict he describes seems psychological, the issue amounts to an ethical struggle between discrimination and equality - a political and philosophical debate of the "Negro Problem" that interrogates the possibilities for achieving an actual democratic social life. The language of psychology identifies and describes the crucial representational conflict between inauthentic and authentic "reality"; and, similarly, the Lafargue Clinic offers a "scientific willingness to dispense with preconceived notions and accept the realities of Negro, i.e., American life" ("Harlem" 301). In his essay on the clinic, Wright engages both its concrete and its philosophical resonance. But first he insists, it "does exist," despite "a widely prevalent feeling among many people that it does not exist" ("Psychiatry" 51). The New York State Department of Social Welfare initially refused the clinic's licensing and funding requests and decided, "there's no need for a psychiatric clinic in Harlem." At the same time, it sent patients to it for care. Without institutional recognition and legitimation, Lafargue, like its patients, existed within contradiction. Many believed the clinic did not exist. Notably, this disbelief parallels what practitioners from the clinic characterize as "the powerful personality conflicts engendered in Negroes by the consistent sabotage of their democratic aspirations ... which easily tips the normal emotional scales toward neurosis." For the psychiatric professionals at Lafargue the false promise of universal democracy affects how black people feel; it illustrates the "intangible truths" of segre- 
gated, American social life. And, rather than agree to the "unreality" of the clinic, or submit to a simple verification of black racial "insanity," Wright, like Ellison, seeks a confrontation with contradiction, with what he calls "idealism protecting corruption." Thus, in "reality" black people are not crazy; their "neurosis" is the "artificially-made psychological problems of Harlem," of racial and economic caste, which, in Wright's words, have been forced sub rosa ("Psychiatry" 49-50).

In a novella originally titled The Jackal, Wright explores the psychic desolation of living within Ellison's "nowhere." The feeling of having no place in the social world defines Wright's 15year-old protagonist, Johnny Gibbs: "For the first time in his life his sensibilities met the naked reality of the world without an intermediary and his heart pounded" (Rite 29). Having lost what Ellison describes as "the bulwarks which men place between themselves and the constant threat of chaos," Johnny's heart forces him to seek refuge and belonging sub rosa, first by meeting a group of boys in the school basement under the cover of night, and then by joining a gang and entering the black criminal underworld. And, unlike the naturalism and social protest that primarily characterize his Native Son (1940), The Jackal (posthumously published as Rite of Passage) explores the psychology of race and alienation. Wright began the novella in 1944 as he completed the final chapters of Black Boy (1945) and as he worked to establish the Lafargue Clinic. Wright's biographer Michel Fabre describes the author's intentions: "[H]e wanted to expose the psychology of a nascent criminal, not write a sociological study of juvenile delinquency." Wright's project also intersects with his stated desire to launch a magazine on crime "which presents so many affinities with art in psychological terms." The magazine would supply authors with outlines for stories and its editorial board of specialists would suggest the "true psychiatric" explanations of murder (Unfinished 503). In his journal Wright describes several discussions of his work-in-progress with his friend Wertham and with a black social psychiatric caseworker from New York's Wiltwyck School for Boys. Through this caseworker, he was able to visit schools, courts, and other institutions concerned with juvenile delinquency and collect information for his new project. Because of his association with the caseworker, Wright himself admits, "I think I'll have the seeds for a damn good psychological study," and declares that the story's drama is "primarily emotional" (Rampersad 35). Rather than seeking to write a naturalistic novel, Wright sought, says Fabre, "to help juvenile delinquents and combat nervous disorders in the ghetto" (Unfinished 272-73). Rite of Passage thus represents an impor- 
tant turning point in Wright's career. In 1945, in a gesture that formally marks his departure from naturalism and from communism, he anticipates his definitive project as one that will describe "a spiritual journey ... not a material one" (Journal 1945). In celebration of Marcel Proust's Remembrance of Things Past (1919), Wright commends the author for his knowledge of the "latest developments in art and science," for his sensitivity to psychoanalytic themes, and for his ability to make them his own. He writes, "I must find something likewise to hang my theme of Negro life upon" (Journal 1945).

Notably, Wright retitled The Jackal as Rite of Passage, in a move that illustrates a shift away from moral concerns toward the notion of a critical turning point in an individual's life. The narrative describes the moment when the state unfeelingly causes Johnny, a Negro, to lose his sense of security, family, and belonging in the world. The boy discovers that his parents and siblings are not his own, that he is a foster child, and for no apparent reason the city has decided to place him with another family. He discovers the corruption that lies beneath the surface and the information is a shock: "only a half hour ago his world had been so solid, real; now he lived in a hot, sick dream" (16). Once an outstanding student and citizen ("A's in every subject. Peaches and cream. ... The world was rosy and he was happy" [3]), Johnny's trauma sends him into "unreality" and toward social dysfunction. The "nowhere" in which he finds himself literally and figuratively relegates him beneath the surface, a condition and a location Wright's new title suggests is of customary, ceremonial significance. Here, the individual story becomes general and indicative of a larger crisis. An impersonal, governmental system had dismissed Johnny's humanity, and, like segregation amid celebrations of democracy, the illogic directs the boy's life and changes him. Indifference and hypocrisy produce another identity: "Then he was still for a long time, filled with a strange sense of void; yet, there was rising up in him, out of a debacle of his former feelings, a new self and, when he became aware of that self, it was already firmly lodged in his mind and heart" (57). Johnny's new, dreamlike condition alters his sensibilities so that the boy becomes a new man whose subjectivity emerges inwardly from within "his mind and heart" rather than being forged in outward behavior. As the narrative suggests, the shock of rejection alters him even before he consciously acknowledges it. And, despite the interior self that surfaces to meet the outward individual, Rite of Passage directs the reader to the arbitrary causes of the protagonist's transformation, "you see, the City folks came and told me that you had to leave us. They didn't say why" (16). 
The state needs no reason to impose itself on the life and destiny of the black boy whose story anticipates The Outsider as the culmination of Wright's research and literary ambition. Rather, in this narrative irrational and institutionalized power breeds a new person.

Without ethical or practical justification for removing Johnny from his home, the city reveals itself as a symbol of the hostile institutions and social environment that order the young man's life. The teenage protagonist in Wright's novella must confront by necessity what Arnold Rampersad calls "the power and carelessness of the white world" and begin living conscious of his alienation (121). Although Rampersad contends, "the age of fifteen is probably rather late for so dramatic a change in an individual's psychology" (124), Wright acutely understood the social and scientific resonance of creating a character whose interiority radically changes during adolescence. A consequence of this change is the psychological tension between perceptions of "real" and "unreal" evident not only in Rite of Passage but also in Wright's concurrent commitment to the Lafargue Clinic. Johnny's actual and psychic condition implicitly invokes the controversy surrounding the clinic and also the figurative schizophrenia Ellison uses to describe the condition in which the imaginary approximates the actual and that for him defines the US: " $[\mathrm{H}]$ is mother's and sister's solid presence seemed unreal . . this was real, was no dream" (13). Moreover, Johnny is at the age in which the initial symptoms of clinical schizophrenia emerge. This coincidence is deliberate. According to Wright, "the Negro is America's metaphor" (White Man 74), and Rite of Passage seeks to make the metaphor literal as it self-consciously attempts to describe the culture of neurosis.

Schizophrenia, notes Otto Fenichel, is "any group of psychotic reactions characterized by withdrawal from reality with highly variable affective, behavioral and intellectual disturbances," and its symptoms consist of "disturbances of association and affectivity, the predilection for fantasy as against reality, and the inclination to divorce oneself from reality" (432). ${ }^{7}$ Wright depicts Johnny's situation as schizophrenic - what he believes to be real is not, and his reality feels like a dream. Similarly, the loss of his family critically prompts associative disturbances. Once he learns the woman who raised him is not his actual mother, he seeks the truth and he finds madness. His friend Billy tells him about his "real" mother: "They said she had demon ... demon something. I can't remember. There was another word. Sounded like tea or something. Oh, yes. They said it was demon preco or something like that. ... [W] [Wen you got it, it seems like you don't 
know what you're doing when you're doing something. Like crazy folks act, see? ... [I]t seems that they put your mother in a ... put her away. You know. In one of those asylums." When Johnny learns that his mother "was awfully sick," he "felt maddened" (48-49). Her institutionalization adds another dimension to Johnny's story and to Wright's metaphor. Both mother and son are "nowhere"; her disorientation precedes his dislocation. Moreover, Billy mispronounces her "sickness"-demon preco is demence precoce, "early deterioration of the mind," later translated into Latin, dementia praecox, by German psychiatrist Emil Kraeplin. Now known as schizophrenia, the term for his mother's illness describes her alienation from "reality." And, since the novella offers no evidence of the mother's actual psychosis, her "deterioration" recalls Wright's characterization of an artificial neurosis as it figuratively articulates the boy's rite of passage: "He was nothing, a nobody; he felt he had no claim upon anybody in the world" (52). Like his mother before him, and like all Negroes conscious of the contradiction that defines their existence in a segregated US, Johnny's self-awareness is the negation that exposes contradiction.

Like Rite of Passage, Ellison's "King of the Bingo Game," also published in 1944 - the year he met Wertham-emphasizes the problem of perception and self-conception that anticipates a literary phenomenology both writers sought to develop. In Ellison's story, misperception characterizes the protagonist's dislocation from reality while it also exposes a hypocritical truth about the world. A nameless protagonist falsely imagines he possesses agency; the man believes he can control a spinning bingo wheel and resolve the psychic and economic burden of his everyday life. Unemployed, Ellison's character has no means to pay the doctor needed to attend his gravely ill wife. Since he believes the $\$ 36.90$ jackpot will ameliorate his dilemma, he approaches the game with a scientific determination. Before the game begins, however, he sits in the theater and he dreams a train is chasing him with "all the white people laughing as he ran screaming ..." (125). At once the racial nightmare enters his real life - the man screams out loud, his seemingly unprovoked cries startle the people around him and announce his dislocation from "reality." At this point the narrative diagnoses the man insane. But if the King of Bingo is schizophrenic, he is a brilliant phenomenologist. Conscious of the fine distinction between sanity and insanity, he is equally rational and insane. The man thinks to himself, "Ask somebody for something and they'd think you were crazy. Well, I ain't crazy. I'm just broke" (124). He knows he is not crazy; rather, the economic and racial caste lying beneath the 
[Ellison and Wright] seek a meaningful engagement with the imposition (and thus the "reality") of racial caste at a moment in American history that celebrates democracy yet denies human equality. surface renders him desperate. The man who imagines himself King of Bingo "felt vaguely that his whole life was determined by the bingo wheel." His problem is material, a lack of mobility, so that in the randomness of the wheel "he felt a profound sense of promise, as though he were about to be repaid for all the things he'd suffered all his life." With that promise "he felt drunk." What the King of Bingo feels defines his consciousness, "there was still that feeling of helplessness within him" (129-30), and also his behavior, "They think I'm crazy. Well let 'em laugh. I'll do what I got to do" (134). The man is unable to let go of his ambition to win the lottery, and like the millions of Negroes in Ellison's America whose goal is complete recognition and full citizenship, the prize seems impossible.

In the postwar era, African Americans expected "real" democracy, and Cold War tensions required the US to reconsider its position on segregation. As Penny M. von Eschen recently argued in Race Against Empire: Black Americans and Anticolonialism, 1937-1957 (1997), the nation would have to eliminate state-sanctioned Jim Crow in order to justify its moral authority as an international power. But, despite legal movements toward integration, the social custom of segregation as racial hierarchy and racial distinction promised the "unreality" of legal equality. This conflict between the law and social custom presented a paradox that black intellectuals sought to make clear. For writers like Wright and Ellison, the promise of integration-one that imagines social equality and the elimination of racial distinction-requires a meaningful confrontation with difference. Integration suggests assimilation, the notion that skin color can lose its invidiousness in the public sphere, that white and black are equal and, consequently, without any meaning that would articulate social value. In their work that privileges psychological discourses, both writers seek a meaningful engagement with the imposition (and thus the "reality") of racial caste at a moment in American history that celebrates democracy yet denies human equality. Moreover, their aesthetic interest in a discursive psychology articulates a consciousness, both universally human and particularly individual, that rejects the long-standing "racial protocol" - the notion that an African-American subjectivity is only exterior-while it advances the notion that, because of their consciousness, individual black people are universally human, not equally white. Although this claim seems obvious and perhaps even elementary, the lesson that because black people think, feel, and write they are both complex and human remains unlearned, an unlearning embodied for Wright and Ellison in segregation as law and racial hierarchy as social custom. 
In order to explain the illogic of the paradox in which they live and work, both become what Ross Posnock calls "antirace race men." Ellison's and Wright's intellectual projects intersect in their rejection of simple, dualistic extremes. Their epistemology engages contradiction and posits the interplay of terms deemed mutually exclusive: black and white, the universal and the particular, public and private, the political and the aesthetic. Their perspective - one that depends on the language of psychology and the metaphor of schizophrenia-amounts to an assault on the cultural status quo. Posnock's discussion of black intellectuals argues that black Americans were "the first modern American intellectuals" since their work challenged "a dichotomized social configuration prevalent in the nineteenth century that kept mind and power, culture and politics, static and separate realms" $(2$, 53). This challenge helped to create "the modern intellectual" and simultaneously the "political public sphere." To regard Ellison and Wright in this light is to recognize their work and the role of American literature as more than an aesthetic practice. Thus, as black men and as intellectuals, Ellison and Wright relish contradiction for it makes literal the tension between art and politics. Because their work privileges interiority, it rejects the more general acceptance of racial exteriority. And, even as their writing promotes social and political equality, it also deliberately seeks an aesthetic freedom that resists the imposition of racial authenticity, of "racial protocol." Consequently, their antirace race writing forces the confrontation with "reality" both men seek.

While locked beneath a wall of glass at the Liberty Hospital, Invisible Man is asked a telling question: "WHO WAS YOUR MOTHER?" The inquiry invokes long-standing protocols of identity by anchoring identity and behavior to blood. Both Freudian and racial, the question's intent seeks to fix the man within stereotype; the protagonist strategically evades the imposition: "I looked at him, feeling a quick dislike and thinking, half in amusement, I don't play the dozens. And how's your old lady today?" (241). His response, first emotional, then intellectual, and finally ironic, defies reductive psychoanalytic and political analyses that would subjugate him to the single collectivity that is his race. Instead, the feelings that lead to an earnest (and frightening) contemplation of identity result in turning the misguided question of identity as familial descent onto the inquirer. The rhetorical question, "how's your old lady today" refuses the identitarian double standard that incarcerates black people in stereotype and in segregation. Here, it is not the protagonist's mother but his mind-his feelings and thoughts - that assumes 
the primary, definitional position since his response is not spoken but contemplated, and since the site of the question and its critique occurs within a psychiatric hospital. Charles Johnson has argued, "it is Mind (the subject pole of experience), not Matter (the object pole), that gives the perceived world its polymorphous character" (16). His point illuminates Invisible Man's subjectivity as well as Ellison's choice to develop a theory of experience most overtly at narrative instances where reason and madness mingle. From this interstice emerges "the lunatic's fancy and the work of art," a powerful conception of reality in an "unreal" world. It raises the stakes concerning aesthetic questions of meaning and history so that both become unstable, subjective, and most importantly, contingent. Just as the "crazy" Vet advises him as they both travel north, "Be your own father young man" (156), Invisible Man ultimately discovers that his multiplicity, his identity - his cosmopolitanism - is his own making, a persona fashioned to survive the maddening contradiction of US society, "[t]he fact is you carry part of your sickness within you" (575). The recognition of that "sickness" ultimately reflects his commitment to paradoxical division as a healthy reality- " $[\mathrm{H}]$ umanity is won by continuing to play in face of certain defeat. Our fate is to become one, and yet many" (577) — and anticipates Gilles Deleuze and Félix Guattari's "schizoanalysis." 8 Their schizoanalytic imagines madness as a radical break from an incarcerating power; Invisible Man finds himself in a psychiatric hospital because he defies authority and by the end of the novel he comes to believe his freedom and his humanity depends on that defiance. Indeed, Freud has been turned upside down. Ellison situates his nameless, faceless protagonist without a father or a mother but within the social world and within a democracy.

Insisting on the primacy of inwardness in literary representation, Ellison and Wright understood the symbolic capital of psychology in the sociopolitical realm. Both endorsed the extraliterary influence of existential philosophy and social psychology on democratic issues of equality and justice. And, although Wright had relocated to Paris before the Supreme Court's Brown v. Board of Education (1954) decision, he continued to serve as a board member of Lafargue. He and Ellison both understood racial distinction as a lunatic obsession and they produced a body of work that would provide critical cultural resonance for the decisive psychological arguments that made segregation unconstitutional. Their friend Wertham had testified for the NAACP at the Delaware litigation that led to the Supreme Court rulings. In addition, the clinic was the site at which crucial studies of black and white children took place. On several occasions in 
Harlem, Wertham and his colleagues examined a racially mixed group of children. Since other tests had been limited to Negroes, the Lafargue group held a special significance for the NAACP attorneys since Wertham's findings could comment on the impact of segregation on the more general population. He concluded that since the social conflict of Jim Crow affected everyone he examined, the children "try to get a correct image of human relationships but fail because in circumstances that affect their lives most vitally they have been given a distorted image" ("Psychological" 96). ${ }^{9}$ As antirace race men, Ellison and Wright - like Wertham - were careful to avoid talk of racial inferiority because such rhetoric was easily turned to racist purposes. Like the legal activists fighting segregation, their emphasis on interiority sought to explode the encrusted assumptions compromising black subjectivity. Their aim was to promote "real" democracy by devaluing the prominence of visible and tangible manifestations of racial hierarchy. In their focus on what lies beneath the surface their work helped to discredit earlier social scientific claims of black racial and biological inferiority. Like Wertham and psychologists Kenneth and Maime Clark, they understood segregation and racial discrimination as part of the tyranny of the visible that damaged blacks and whites alike. ${ }^{10}$

The Clarks', Werthams', and others' characterizations of what Ellison called a "nation of ethical schizophrenics" highlight the critical emphasis on the insidious contradiction of segregation and democracy, a perspective overruled, in effect, by the false notion of black pathology. The now well-known ruling in Brown about the "intangible considerations" of segregation misreads the ethical and political critique of democracy by excluding Wertham's earlier testimony. In addition to the well-documented "feelings" of segregated black children, Wertham found that in "the white children we found a subtle, though definite tendency to identify unconsciously with Negro children." Before the Delaware court Wertham stated that both black and white children suffered an "unsolveable emotional conflict" and that they interpret segregation "in one way and only one way - and that is they interpret it as punishment" (qtd. in Kluger 444). ${ }^{11}$ However, the Supreme Court later translated this psychological evidence as not only having an effect on "the importance of education to our democratic society" as it "is the very foundation of good citizenship," but also as a denial of Negro children's equal protection guaranteed by the Fourteenth Amendment. In order to discredit the logic of "separate but equal" the Court would have to recognize inequality as a direct result of racial separation. It then concluded that for Negro children segregation "generate[s] a feel- 
ing of inferiority as to their status in the community that may affect their hearts and minds in a way unlikely ever to be undone" (Brown 691). Those feelings now perceived as a social scientific justification for black American inferiority were initially understood as a tactical articulation of the "intangible" evidence that would undermine segregationist claims of the tangible equality of separate facilities and curricula. In order to win public support for the notion of integration as a bulwark against assaults on American democracy, the antisegregationist position depended on psychological language.

Concerning the psychological resonance of the Court's decision, historian Daryl Michael Scott writes, "When it came to damage imagery, the radicals took their intellectual cue not from Fanon or Malcolm X but from Ralph Ellison, the novelist and proponent of a weak brand of pluralism," and from "Richard Wright, the inspiration of the postwar pathologist" (166-67). As Scott's work confirms, Ellison's and Wright's engagement with psychological discourses helped to facilitate one of the most significant transformations in twentieth-century US history. However, he understands their narrative interests in interiority as an effort to manipulate the therapeutic sensibilities of whites and ultimately to earn their acceptance. Scott's criticism not only ignores the insistence of Ellison, Wright, and others that whites also suffered from the hazards of segregation, but also overlooks the schizophrenic metaphor that critically illuminates the lie of American democracy. As early as 1935, legal activists seeking racial equality worked to discredit the Social Darwinist authority that validated racial hierarchy. The Crisis reported that successful litigation would have "to use every legitimate means ... to accomplish actual equality of educational opportunities" (qtd. in Baker 192). Only a paradigmatic shift in social scientific discourses could facilitate this change, so that 10 years before the Supreme Court decision and two years before Lafargue's opening, it is no surprise that one critic writes, "[M]odern psychological warfare is being waged on the American color front" (Mason 13). The project of granting African Americans full subjectivity and legal equality would require a consideration of more than skin color, of what lies beneath the surface, of psychology. Recognizing this historical turn toward psychology at the postwar moment, anthropologist Lee D. Baker offers an account of the ways in which social psychologists and social anthropologists influenced by psychology assumed critical authority over biologists and cultural anthropologists. According to Baker, legal briefs advocating integration employed psychiatrists and psychologists who were able to discredit an earlier social science and were able 
"to testify that no scientific rationale existed to classify the races and that African Americans were not inferior to White Americans" (201). In effect, psychology would refute biological justifications of white supremacy.

Ellison's and Wright's risk of "staging a mental theater" contests the belief that psychological discourses concerning black racial interiority endorse pathology and inferiority and it extends Du Boisan, self-reflexive double consciousness (Spillers 136). Their stress on psychological being affords self-perception within a moment when racist contradiction threatens to negate individual and collective black subjectivity and their narratives function to make the intangibles of contradiction visible. When the King of Bingo first recognizes that his life feels like a nightmare, when he experiences a discrepancy between what he sees and what actually exists, a "strange sensation played over his skin" (125). This tension between perception and reality manifests itself on the man's body. Similarly, upon realizing the hospital is not actually concerned with his health, Invisible Man recalls, "my skin itched all over" (231). In The Outsider, Damon declares, "the body reflects the soul" (9), a version of "mental theater" that achieves critical significance with the acknowledgement of the deliberate coincidence that he also has the "feeling as though something were creeping over his skin" $(284,122)$. In each instance, intangibles - feelings and perceptions - originate from within and then become projected externally. Concerning double consciousness Spillers writes, "It is not enough to be seen; one was called upon to decide what it meant" (143), and she advocates a psychoanalytic cultural analysis that explains "a subject in discourse crossed by stigmata, or the nonfantastical markings of history whose shorthand is 'race'" (142). Spillers's theory clarifies Ellison and Wright's underdiscussed and often ignored practice within what she calls the "psychoanalytic" (145). The metaphor of schizophrenia, for example, illustrates not how it looks but what it means to live as a contradiction, as both Negro and American. Literal characterizations of individual psychologies deny the negation real-life racism manifests; it makes "nowhere" visible by revealing what Posnock calls "The Unclassified Residuum," the "paradoxical absurdities" that constitute black existence (64). Thus, when critic Phillip Brian Harper cogently describes a failed instance of Lacanian "self-idealization" in which Invisible Man cannot see himself reflected in the mirror of Mr. Norton's car, the reader can turn to other narrative moments that explain what that negation means and also how it feels. ${ }^{12}$

At the factory hospital, Invisible Man tries to discern his 
location, the causes of his present condition and its significance. He knows he lies in a hospital- "They would care for me. It was all geared toward the easing of pain" (233) — but he soon discovers their interest depends on altering his perception and his behavior. "Our concept is Gestalt" (236) - their shock therapy disregards the man's physical and existential anguish. The reader and the protagonist soon discover that Invisible Man's feelings and his response have no value in the "scientific" practice that imagines a "cure" for his alienation. "I was pounded between crushing electrical pressures ... each time my breath returned I yelled, punctuating the rhythmical action of the nodes." Like the hospital workers, the reader can see the protagonist suffer. But for the hospital workers the man's condition remains in a single dimension; unlike the reader, they refuse to recognize "the lower frequencies" that articulate the "intangibles" that lend meaning to experience (581). Concerning his treatment, one of the hospital workers asks, "But what of his psychology?" and meets the response, "Absolutely of no importance!" (236). Even as they attempt a "therapy" meant to realign Invisible Man's relation to social "reality," his feelings neither matter nor have influence. Their ignorance becomes apparent to the reader, who, because she has access to the man's psychology, has the ability not only to see the man's invisibility, but, as Harper and Spillers argue, to apprehend what it means.

That denial of meaning takes on special significance at narrative moments when the tension between sanity and insanity is most vivid. At the psychiatric hospital, Invisible Man "discovered that I was not lying on an operating table but in a kind of glass and nickel box" (233), and he begins to understand his condition in terms of his location. Like the crowded, segregated Harlem Ellison describes in "Harlem Is Nowhere," the place Invisible Man finds himself is "cramped." Even as he registers a complaint concerning the discrete and stifling quarters in which he must meet his "treatment," the people who confine him explain, "Don't worry about it, boy. You'll get used to it after a while" (235). Here, Ellison's narration begins to illustrate both sides of the paradox he and Wright seek to describe. The "reality" that Invisible Man (like Johnny Gibbs's mother) is locked in an asylum for no discernable reason contradicts the "reason" that lends authority to his "treatment." Beneath the glass the patient looks insane, but because the reader approaches the story from the patient's interiority - from his psychology - she pierces the veil of appearances.

For Ellison's protagonist, "Faces hovered above me like inscrutable fish peering myopically through a glass aquarium wall." 
From his view fragmented bodies, "first their heads, then the tips of their finlike fingers," present the reality of his present condition as surreal. They look crazy, and in his dislocation, "A terrible sense of loneliness came over me." Invisibility becomes alienation and absurdity, "They appeared utterly stupid and I didn't like it. It wasn't right." The discontinuity Ellison describes here becomes multiple and vivid; and, as if in answer to Spillers's call, Invisible Man seeks to make sense of the scene: "But we are all human, I thought, wondering what I meant" (239). Split between thinking and meaning, Invisible Man cannot confirm his existence; his inability and effort to confirm this Cartesian syllogism not only drives the novel's plot but demands that he follow the "crazy" Vet's advice to "learn to look beneath the surface. ... Even if it lands you in a straight jacket or a padded cell" (153).

Like the electrified rug that shocks the protagonist during the Battle Royal, the "therapy" at the factory hospital rejects the possibility of Invisible Man's agency and humanity. This denial promotes an alternate reality that reveals a "schizophrenia" not in the black protagonist, but in the people and the society that abide strictly with an external view of black humanity. In an unpublished draft of the hospital scene Ellison makes this fixation on the surface even more vivid, "But how, it suddenly occurred to me, could they learn so much about me ... from the outside of the case?" ("Hospital" 269). In their effort to "cure" Invisible Man, the hospital workers ignore his interiority and fail to recognize his personhood. From beneath the glass the protagonist observes their fantasy and takes a breath that becomes a burp and an "interruption to the smooth function of the machine." At this moment of resistance, "Hell broke loose" ("Hospital" 270); initially the hospital workers cannot account for the disruption, but when a worker discovers the protagonist had burped, the interlocutors are shocked. Ellison writes, "He, for a moment at least, was aware of a process originating within me. Thanks, humanist." However banal, the burp demands an admission that the superficial examination and treatment denies. The burp and its observation become a forced exchange that suggests human possibility; it causes the protagonist to reconsider the object of his "cure." Concerning the issue of his identity, Invisible Man realizes "for all the questions they'd put to me, they had made no provision for hearing my answers! . . What was their game? Why ask questions that couldn't be answered through the glass? What did they expect?" ("Hospital" 271). In the novel Ellison suggests the answer: "A kind of combat" that links the meaning of his identity with the conflict that compromises his personhood and 
with the contradiction that promises his freedom (242), "When I discover who I am, I'll be free" (243). And, like the burp that emerges from within, Invisible Man's self-understanding and autonomy will not be the product of external creation.

"To live amidst others without an identity was intolerable. In a strict sense he was not really in the world; he was haunting it, pleading for entrance into life" (132). Wright declares this in The Outsider, confirming as well the exigency with which Ellison's protagonist seeks self-definition and authentic social exchange. Like Invisible Man, Wright's Cross Damon pursues an individual identity that would grant freedom and humanity. Because of their concern with questions of alienation, individuality, responsibility, and freedom, both novels have been associated with existentialism more than with psychology. Indeed, by 1945 Ellison had introduced his friend to French existentialism. Both writers had read Søren Kierkegaard, Jean-Paul Sartre, and others in an attempt to reconcile their aesthetic and political commitments; and, since Wright lived in Paris as The Outsider was written and published, the novel has been often dismissed as Wright's "philosophical roll in the hay." But, despite Wright's obvious and sometimes awkward display of existentialist theory, his interest in existentialism emerges from his prior commitment to psychology. Wright believed The Outsider was his first literary effort "projected out of a heart preoccupied with no ideological burden save that of rendering an account of reality" (Fabre, "Richard Wright" 119). Similarly, when Ellison shares his interest in existentialism with his friend he writes, "their psychological probing has produced a powerful art" (Letter to Richard Wright). Thus, The Outsider can be considered a psychological novel that extends the existentialist concerns apparent in "The Man Who Lived Underground" (1941) and anticipates the psychoanalytic themes in Savage Holiday (1954) and The Long Dream (1959). Although Cross Damon is often regarded as a symbol of a problematic Christian ethic and of Nietzschean demonism, Damon recalls significantly Johnny Gibbs's “demon preco.” Both are psychological metaphors for a more general social condition. In the novel Damon's crimes are not evil but amoral, he "is the twentieth century writ small" (283). His story is not primarily racial; Wright declares that in The Outsider, "I was trying to grapple with the big problem - the problem and the meaning of Western civilization as a whole" (Smith 37). Like Invisible Man, his problem is at once particular and universal. Psychology reveals this simultaneity, its paradox, and its larger implications.

Even before Damon chooses to discard his identity and invent a new self, he cannot confirm the Cartesian bias toward 
cognition at the expense of the body: "He was despairingly aware of his body as an alien and despised object over which he had no power, a burden that was always cheating him of the fruits of his thought" (13). Damon begins to experience the metaphorical schizophrenia that characterizes the moment, "his tensions began to deform the look of the world" so that what he feels becomes the "reality" that he sees (126). His subsequent conversation with Ely Houston, another "outsider," thus turns toward psychology as the necessary site at which to discern the particular meaning of being black in America as well as its universal implications: "Negroes, they are going to be both inside and outside of our culture at the same time. Every emotional and cultural convulsion that ever shook the heart and soul of Western man will shake them . . . Negroes . . . will become psychological men, like the Jews. ... They will not only be centers of knowing, so to speak... . The political, social, and psychological consequences of this will be enormous . . " (129). Now, Wright's Negro has become more than America's metaphor. As a "psychological" man he represents possibility. His condition anticipates Wright's description of "a quarrel with the West" in White Man, Listen! Lectures in Europe, 1950-56 by suggesting the meaning and the consequences of a paradoxical alienation (3), of what he calls "the problem of distance, a psychological distance" (7). As outsiders, Damon and Houston, his disabled Jewish counterpart, literally embody the era's phenomenological transition - a transition concerned with postwar humanist claims as well as one engaged deeply in fundamental questions about racism and colonialism. ${ }^{13}$ The underground accident that eliminates the burden of his past promises freedom in the future. Although Damon cannot escape the pessimism within himself, his self-perception and even his amorality, "That a man who kills like that is a bleak and tragic man" (283), reflect a crisis in the more general human condition.

What distinguishes Ellison and Wright is the exigency with which they portray black racial interiority. By 1946 and the emergence of the Lafargue Clinic, Ellison and Wright describe the crucial American Dilemma as an ethical, intellectual, and psychological conflict that borders on insanity. In the words of the Vet, both Ellison and Wright "raise the ante" (153). The risk of promoting the notion that, indeed, black people were "crazy anyway" would increase the priority and the effort to resolve the hypocritical denial of universal humanity and democracy in the US by forcing a "shock" of "reality." Like the "objectivity" of psychiatric shock therapy, Ellison and Wright's engagement with psychology disturbs the madness that promotes inequality and 
imagines it sane. As a metaphor, schizophrenia illustrates and defines this paradox while it rescues black people from the depths of segregation and pity.

\section{Notes}

1. St. Phillip's Episcopal Church, 215 W. 133rd Street, New York City. The clinic's success prompted development plans for a state-sponsored psychiatric clinic at Harlem Hospital, under the direction of Dr. Harold Ellis. See Lafargue Clinic Records. Concerning the plans for Harlem Hospital's Clinic, see Curtis.

2. Born and trained in Germany, Wertham is best known for his arguments concerning the negative psychological influence of comic books on children that culminated in The Seduction of the Innocent (1954). As an expert witness for the defense at several criminal trials, he offered testimony concerning the psychoanalytic causes of certain types of violent behavior. When Lafargue opened, Wertham was also the director of the Mental Hygiene Clinic at Queens General Hospital, New York, and president of the Association for the Advancement of Psychotherapy.

3. Wright and Wertham met and became friends in 1941. Both studied the details of the murder conviction of Clinton Brewer; and, while Wertham served as an expert witness for the man's second criminal trial, Wright used Brewer's story to outline the narrative that, inspired by Wertham's Dark Legend, A Study in Murder (1941), became Savage Holiday. Wertham also published a psychological study of Wright's Native Son, "An Unconscious Determinant in Native Son" (1944). While working for the Merchant Marine Union in 1944, Ellison sought exemption from the draft and service in a segregated army. Wright referred him to his friend. Wertham for what he characterized as a "psychiatric out." See Wright's journal entry dated 22 January 1945 . Ellison met and became friends with Wertham in 1944; the details of their meeting and subsequent friendship remain vague since Wertham's papers at the Library of Congress remain closed until 20 May 2002 and since a significant section of Ellison's papers, also at the Library of Congress, remain restricted. Forthcoming critical biographies on Ellison by Lawrence P. Jackson (Ralph Ellison: Emergence of Genius [2001]) and Rampersad should illuminate more of these details. Jackson and Rampersad have generously shared their insights and their research with me.

4. In addition to Myrdal's An American Dilemma, several postwar cultural critics identified the problem of segregation as one that affected the "hearts and minds" of all Americans. See also "Prejudice: Our Postwar Battle" (1945) and Harry S. Ashmore, Hearts and Minds: The Anatomy of Racism from Roosevelt to Reagan (1982), esp. 82-206. Articles on the Lafargue Clinic in mainstream magazines also understood that, with the promise of integration, the salient features of the social manifestations of racial difference were increasingly private and interior. See "Clinic for Sick Minds" (1948) and "Psychiatry in Harlem" (1947). By the 1950s, psychology became one of the most popular means to discuss the "Negro Problem." See, e.g., Charles I. Glicksberg, "Psychoanaly- 
sis and the Negro Problem" (1956), and Martin M. Grossack, "Psychological Research and the Negro" (1956).

5. Many of Ellison and Wright's contemporaries wrote psychoanalytically engaged novels. Mary Jane Ward's The Snake Pit (1946) enjoyed heavy sales and, along with its film adaptation, helped increase the public visibility of mental hospitals. Jo Sinclair, author of Wasteland (1946) and The Changelings (1955), among others, also published an article celebrating the work at Lafargue. See Sinclair, "Authors Are Like People" (1946). Wertham served as a consultant for filmmaker Alfred Hitchcock; and the film Home of the Brave (1949) features an African-American soldier whose psychic trauma is not the violence of war, but the assault of racial discrimination. Ann Douglas recently described American psychiatrists in the first two decades of the Cold War as hotly interested in "the psychopath," an admittedly imprecise term used to designate a person beyond the reach of social values, one who failed to internalize the norms of social behavior. She documents the popularity of Freudian psychoanalysis, Reinhold Niebuhr and Fyodor Dostoyevsky's novels as evidence of the era's interest in "self-scrutiny and the darkness such scrutiny reveals." She characterizes its discursive features as "a form of extreme displacement, language split off from visible reality." See Douglas, "Periodizing the American Century: Modernism, Postmodernism, and Colonialism in the Cold War Context" (1998). Janet Walker's Couching Resistance: Women, Film, and Psychoanalytic Psychiatry (1993), esp. 1-23, offers a detailed account of the tremendous rise of psychiatry, psychology, and social work in the postwar decades.

6. The promise of integration had certainly influenced African-American intellectuals' sense of their future as writers. I discuss this critical turning point in my manuscript Post-Black: Race, Writing and Integration. In an issue of W. E. B. Du Bois's journal Phylon, a group of black intellectuals were asked, "Would you agree with those who feel that the Negro writer, the Negro as subject, and the Negro critic and scholar are moving toward an 'unlabeled' future in which they will be measured without regard to racial origin and conditioning?" The question was meant to highlight the integrationist moment as well as the "universalist" trend. The responses describe a Jim Crow aesthetic in decline and anticipate an emerging "freedom" from its confines. See Hill and Holman.

7. Fenichel's definition is especially revealing not only because it was understood as an authoritative reference source and was published as Wright and Ellison worked to establish Lafargue, but also because Wright owned the book. See also Michel Fabre, ed., Richard Wright: Books and Writers (1990).

8. Notably, at the same moment prominent critic Lionel Trilling is also celebrating the notion that intellectual maturity, or "reality," consists of the ability to hold contradictory ideas in tension rather than to commit to a single ideology. See his chapter "Reality in America" in The Liberal Imagination, esp. 1-19.

9. In 1951 specialists at the Lafargue Clinic examined 13 Delaware school children. Eight of the children were black Americans and five were white Americans; all were selected at random from four different locations within the state. Using individual case histories, individual interviews, group observation, group discussion, drawing tests, mosaic tests, and Rorschach tests, Wertham and his colleagues concluded that, since segregation is a "negative health fac- 
tor," it was a general "public health problem." The examinations at the clinic were the first of their kind. See Wertham's "Psychological Effects of School Segregation" (1952) and "Psychiatric Observations on the Abolition of School Segregation" (1953).

10. Kenneth Clark's "Effect of Prejudice and Discrimination on Personality Development" (1950) was the first psychological study listed in the decisive footnote in the Brown decision. The citation also included Max Deutscher and Isidor Chein, "The Psychological Effects of Enforced Segregation: A Survey of Social Science Opinion" (1948) and Myrdal's An American Dilemma. It is important to note that the decision does not include the primary publication emerging from the Clarks' well-known "Dolls Test." See their "Racial Identification and Preference in Negro Children" (1947).

11. On 23 October 1951, the New York Times reported Wertham's testimony that "an equally adverse effect was noted in the white children" (Dales). Wertham's testimony also appears in Richard Kluger, Simple Justice: The History of Brown v. Board of Education and Black America's Struggle for Equality (1977).

12. Harper's argument more specifically considers the question of AfricanAmerican male subjectivity as "a function of the social interrelation of blacks and whites." His work also engages concerns about postmodernity and capitalism; and it is especially resonant here since Jacques Lacan, like Wertham, was Ellison's contemporary. Using Lacan's psychoanalytic theory to explore the issue of individual black subjectivity, he emphasizes the multiplicity and contradiction I discuss here. For Harper, the question of individual black subjectivity is "not so much as the negation conventionally believed to emblematize it but rather always as potentially unfulfilled, simultaneous promise and disappointment" (116).

13. By the 1950s Wright, more than Ellison, began to think of psychoanalysis as a means to articulate issues that extended beyond the US. His residency in Paris, his travels throughout Europe, Africa, and Asia as well as his friendships with Aimé Césaire, Simone de Beauvoir, Frantz Fanon, Jean-Paul Sartre, and Leopold Senghor helped to expand his interest in global concerns. In January 1947, Wright helped Césaire, Senghor, and Alioune Diop launch Presence Africaine. See also his Black Power (1954), The Color Curtain (1955) and Pagan Spain (1957). For a detailed treatment of Wright's transnationalism, see Manthia Diawara 59-77 and Paul Gilroy 146-86.

\section{Works Cited}

Ashmore, Harry S. Hearts and Minds: The Anatomy of Racism from Roosevelt to Reagan. New York: McGrawHill, 1982.

Baker, Lee D. From Savage to Negro: Anthropology and the Construction of Race, 1896-1954. Berkeley: U of California P, 1998.
Bendiner, Robert. "Psychiatry for the Needy." Tomorrow May 1946: 22-26.

Brown v. Board of Ed. 347 US 483. Sup. Ct. 1954.

Clark, Kenneth B. "Effect of Prejudice and Discrimination on Personality Development." Midcentury White 
House Conference on Children and Youth. Washington, DC: Government Printing Office, 1950.

Clark, Kenneth B., and Maime P. Clark. "Racial Identification and Preference in Negro Children." Readings in Social Psychology. Ed. Theodore Newcomb and Eugene Hartley. New York: Holt, 1947. 602-11.

“Clinic for Sick Minds." Life 23 February 1948: 99-102.

Curtis, Constance. "Mental Hygiene Clinic Planned in the Harlem Area." Amsterdam News 18 May 1946: n. pag.

Dales, Douglas. "Public Segregation Held Health Drag." The New York Times 23 October 1951: 1.

Deutscher, Max, and Isidor Chein. "The Psychological Effects of Enforced Segregation: A Survey of Social Science Opinion." The Journal of Psychology 26 (1948): 259-87.

Diawara, Manthia. In Search of $A f$ rica. Cambridge: Harvard UP, 1998.

Douglas, Ann. "Periodizing the American Century: Modernism, Postmodernism, and Colonialism in the Cold War Context." Modernism/Modernity 5.3 (1998): 74-97.

Ellison, Ralph. "Beating That Boy." 1945. Ellison, Shadow 95-102.

"Harlem Is Nowhere." 1948.

Ellison, Shadow 294-302.

"Hospital Scene and Escape." 1949. Ralph Ellison Papers. Box 49. Library of Congress, Washington, D.C.

Vintage, 1995.

"King of the Bingo Game."

Flying Home and Other Stories. Ed.
John F. Callahan. New York: Viking, 1996. 123-36.

1945. . Letter to Richard Wright.

Shadow and Act. New York:

Vintage, 1995.

Fabre, Michel. "Richard Wright and the French Existentialists." The Critical Response to Richard Wright. Ed. Robert J. Butler. Westport, CT: Greenwood, 1995. 139-59.

The Unfinished Quest of Richard Wright. Urbana: U of Illinois P, 1993.

Fenichel, Otto. The Psychoanalytic Theory of Neurosis. New York: Norton, 1945.

Gilroy, Paul. The Black Atlantic: Modernity and Double Consciousness. Cambridge: Harvard UP, 1993.

Glicksberg, Charles I. "Psychoanalysis and the Negro Problem." Phylon: The Atlanta University Review of Race and Culture. 12.1 (1956): 41-51.

Grossack, Martin M. "Psychological Research and the Negro." Phylon: The Atlanta University Review of Race and Culture. 12.1 (1956): 70-73.

Harper, Phillip Brian. “"To Become One Yet Many': Psychic Fragmentation and Aesthetic Synthesis in Ralph Ellison's Invisible Man." Framing the Margins: The Social Logic of Postmodern Culture. New York: Oxford UP, 1994. 116-44.

Hill, Mozell C., and M. Carl Holman, eds. The Negro in Literature. Spec. issue of Phylon: The Atlanta University Review of Race and Culture. 11.4 (1950): 296-394.

Johnson, Charles. Being and Race: Black Writing Since 1970. Bloomington: Indiana UP, 1990. 
Kluger, Richard. Simple Justice: The History of Brown v. Board of Education and Black America's Struggle for Equality. New York: Vintage, 1977.

Lafargue Clinic Records. Box 1. Schomburg Center for Research in Black Culture. New York Public Library.

Martin, Ralph G. "Doctor's Dream in Harlem." New Republic 3 June 1946: 798-800.

Mason, Ann E. "Streamlined Jim Crow Psychology." Quarterly Transcope: A Crossview of Negro Life (autumn 1944): 13-15.

Myrdal, Gunnar. An American Dilemma: The Negro Problem and Modern Democracy. New York: Pantheon, 1944.

Posnock, Ross. Color and Culture: Black Writers and the Making of the Modern Intellectual. Cambridge: Harvard UP, 1998.

"Prejudice: Our Postwar Battle." Look 1 May 1941: 47-51

"Psychiatry in Harlem." Time 1 Dec. 1947: 50-52.

Rampersad, Arnold. Afterword. Rite of Passage. By Richard Wright. New York: HarperCollins, 1994. 132-48.

Scott, Daryl Michael. Contempt and Pity: Social Policy and the Image of the Damaged Black Psyche, 18801996. Chapel Hill: U of North Carolina P, 1997.

Sinclair, Jo. "Authors are Like People." New York Post 9 May 1946: 45-46.

Smith, William Gardner. "Black Boy in Paris." Ebony July 1953: 36-37.

Spillers, Hortense. "All the Things You Could Be By Now, If Sigmund
Freud's Wife Was Your Mother." Female Subjects in Black and White: Race, Psychoanalysis and Feminism. Ed. Elizabeth Abel et al. Berkeley: U of California P, 1997. 135-58.

Tate, Claudia. Psychoanalysis and Black Novels: Desire and the Protocols of Race. New York: Oxford UP, 1998.

Trilling, Lionel. The Liberal Imagination: Essays on Literature and Society. New York:Viking, 1950.

Walker, Janet. Couching Resistance: Women, Film and Psychoanalytic Psychiatry. Minneapolis: $U$ of Minnesota P, 1993.

Wertham, Frederic.. "Psychiatric Observations on the Abolition of School Segregation." Journal of Educational Sociology 26.7 (1953): 24-27.

- "Psychological Effects of School Segregation." American Journal of Psychotherapy 6:1 (1952): 94-103.

-. "Super-Ego and Surplus Value." New Republic 28 Jan. 1946: 129-30.

"An Unconscious Determinant in Native Son." Journal of Clinical Psychology 6 (July 1944): 113-14.

Wright, Richard. Journal. 22 January 1945. Richard Wright Papers. Box 49. Beinecke Library, Yale University.

- The Outsider. New York: HarperPerennial, 1995.

- "Phychiatry [sic] Comes to Harlem." Freeworld Sept. 1946: 45-51. Rite of Passage. New York: HarperCollins, 1994.

White Man, Listen! Lectures in Europe, 1950-56. New York: HarperPerennial, 1995. 